\title{
SYNTHESIS, CHARACTERIZATION, ELECTRICAL AND CATALYTIC STUDIES OF SOME COORDINATION COMPOUNDS DERIVED FROM UNSYMMETRICAL SCHIFF BASE LIGAND
}

\author{
Gaurav B. Pethe, Amit R. Yaul and Anand S. Aswar* \\ Department of Chemistry, Sant Gadge Baba Amravati University, Amravati-444 602, M.S., \\ India
}

(Received June 15, 2014; revised September 10, 2015)

\begin{abstract}
New unsymmetrical tetradentate Schiff base ligand derived from 5-chloro-2hydroxyacetophenone, 2-hydroxy-5-methyl-3-nitro acetophenone and carbohydrazide and its complexes with $\mathrm{VO}(\mathrm{IV}), \mathrm{Cr}(\mathrm{III}), \mathrm{Mn}(\mathrm{III}), \mathrm{Fe}(\mathrm{III}), \mathrm{MoO}_{2}(\mathrm{VI}), \mathrm{WO}_{2}(\mathrm{VI}), \mathrm{Zr}(\mathrm{IV})$ and $\mathrm{UO}_{2}(\mathrm{VI})$ have been prepared. They were characterized by elemental analysis, IR and electronic spectra, magnetic susceptibility measurements and thermal analyses. The Schiff base ligand has also been characterised by ${ }^{1} \mathrm{H}-\mathrm{NMR}$ spectroscopy. The thermal behaviour of metal complexes shows that the hydrated complexes lose water molecules of hydration in the first and then is immediately followed by decomposition of ligand molecule in the subsequent steps. The IR spectra suggest that ligand acts as dibasic tetradentate nature and coordination takes place through azomethine nitrogen and phenolate oxygen. The crystalline nature of the VO(IV) complex was conformed through the powder XRD analysis. The catalytic activity of the $\mathrm{VO}(\mathrm{IV})$ and $\mathrm{Mn}(\mathrm{III})$ complexes have been tested in the epoxidation reaction of styrene and conversion of styrene were $11.14-24.35 \%$ and $9.64-23.42 \%$, respectively. The solid state electrical conductivity of ligand and its complexes were measured, which could obeyed the relation $\sigma=\sigma^{0} \exp \left(\mathrm{E}_{\mathrm{a}} / \mathrm{KT}\right)$ over the temperature range $313-413 \mathrm{~K}$.
\end{abstract}

KEY WORDS: Schiff base, Metal complexes, TGA, Electrical conductivity, XRD, Oxidation of styrene

\section{INTRODUCTION}

The Schiff base ligands are an important class of organic ligands in coordination chemistry, which increase the chemical and biological aspects of the compounds because they act as antibacterial, antiviral, antifungal agents, as homogeneous or hetrogeneous catalysts and display magnetic properties [1-4]. Schiff bases offer a versatile and flexible series of ligands due to easily preparation, diversity of structures, and providing the effects of steric interactions on coordination geometries and many applications [5]. Multidentate Schiff bases generate stable complexes with most metallic ions and especially with transition ones and have ability to stabilize them in various oxidation states. During the past decades, considerable attention has been paid to the chemistry of the metal complexes of with symmetrical Schiff base ligands containing $\mathrm{N}$ and other donors atoms. However, very little information is available for metal complexes of unsymmetrical Schiff base ligands [6-9]. Unsymmetrical Schiff base ligands derived from substituted carbohydrazide have played an important part in revealing the preferred coordination geometries of metal complexes and have valuable importance in the coordination chemistry due to their preparative accessibility and structural variability. The preparation of the metal complexes of unsymmetrical Schiff base of carbohydrazide and substituted hydroxyl acetophenone has come from the desire to form simple unsymmetrical complexes for their physicochemical characterization and structural elucidation. Here in we describe the synthesis and characterization of the unsymmetrical Schiff base ligand derived from 5-chloro-2-hydroxy acetophenone, 2-hydroxy-5-methyl-3-nitro acetophenone and carbohydrazide and its metal complexes involving tri-, tetra-, and hexavalent metal ions.

\footnotetext{
*Corresponding author. E-mail: aswaranand@gmail.com
} 


\section{EXPERIMENTAL}

All the chemicals and solvents were of analytical grade and used as received without further purifications. Vanadyl sulfate pentahydrate, chromium chloride hexahydrate, anhydrous ferric chloride, dioxotungsten, tetrathiocyanate, zirconium acetate, uranyl nitrate hexahydrate and carbohydrazide were obtained from Rankem and SD fine chemicals (Mumbai, India). $\mathrm{Mn}(\mathrm{OAc})_{3} \cdot 2 \mathrm{H}_{2} \mathrm{O}$ was prepared by the oxidation of $\mathrm{Mn}(\mathrm{OAc})_{2} \cdot 4 \mathrm{H}_{2} \mathrm{O}$ using Christensen' method [10] and bis(acetyl acetonato) dioxomolybdenum(VI) was synthesized according to literature method [11].

\section{Preparation of Ligand $\left(\mathrm{H}_{2} \mathrm{~L}\right)$}

The ligand N-[1-(5-chloro-2-hydroxyphenyl)ethylidene]-N'-[1-(2-hydroxy-5-methyl-3-nitrophenyl)ethylidene] carbonohydrazide was prepared by dropwise addition of equimolar amounts of 5-chloro-2-hydroxy acetophenone $(2.4 \mathrm{~g}, 0.016 \mathrm{~mol})$ to 2-hydroxy-5-methyl-3-nitro acetophenone $(3.12 \mathrm{~g}, 0.016 \mathrm{~mol})$ with stirring at room temperature. This resulting reaction mixture was reacted with a hot ethanol-DMF solution $(60: 40 \mathrm{v} / \mathrm{v} ; 25 \mathrm{~mL})$ of carbohydrazide $(1.44$ g., $0.016 \mathrm{~mol})$ and mixture was refluxed on sand bath for about $9 \mathrm{~h}$ at $225^{\circ} \mathrm{C}$. The solvent was then partially evaporated in air and faint yellow coloured compound obtained was filtered and washed it with ethanol, petroleum ether and dried in vacuum over anhydrous $\mathrm{CaCl}_{2}$. The synthesized ligand was crystallized and conformed though its melting point $313{ }^{\circ} \mathrm{C}$ (yield: $72 \%$ ) and its NMR analysis as follows: $12.68(\mathrm{~S}, 1 \mathrm{H}, \mathrm{OH}$, phenolic), $14.30(\mathrm{~S}, 1 \mathrm{H}, \mathrm{OH}$, phenolic), $10.19(\mathrm{~S}, 1 \mathrm{H}$, imino, $\mathrm{NH}), 10.23(\mathrm{~S}, 1 \mathrm{H}$, imino, $\mathrm{NH}), 2.12\left(\mathrm{~S}, 3 \mathrm{H}, \mathrm{Ar}-\mathrm{CH}_{3}\right), 2.31\left(\mathrm{~S}, 3 \mathrm{H}, \mathrm{CH}_{3}\right)$, $2.36\left(\mathrm{~S}, 3 \mathrm{H}, \mathrm{CH}_{3}\right), 6.91-7.95(\mathrm{~m}, 5 \mathrm{H}$, aryl-H). The schematic representation of the synthesis of ligand $\mathrm{H}_{2} \mathrm{~L}$ is shown in Figure 1.
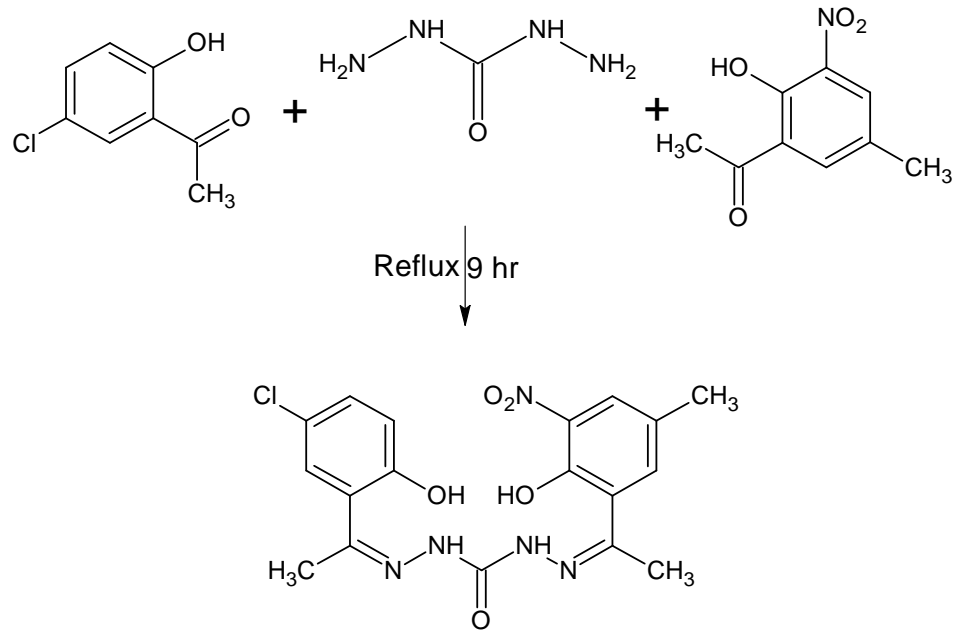

Figure 1. Scheme for the synthesis of ligand.

Synthesis of $\mathrm{VO}(\mathrm{IV}), \mathrm{Cr}(\mathrm{III}), \mathrm{Mn}(\mathrm{III}), \mathrm{Fe}(\mathrm{III}), \mathrm{MoO}_{2}(\mathrm{VI}), \mathrm{Zr}(\mathrm{IV})$ and $\mathrm{UO}_{2}(\mathrm{VI})$ complex

The complexes were prepared by refluxing equimolar solution of hot DMF $(25 \mathrm{~mL})$ of the organic ligand $(0.016 \mathrm{~mol})$ with a hot ethanol solution of the appropriate metal salt $(0.016 \mathrm{~mol})$ on sand bath for 6-7 $\mathrm{h}$ at $270-300{ }^{\circ} \mathrm{C}$ depending on the metal salt used. On cooling to room

Bull. Chem. Soc. Ethiop. 2015, 29(3) 
temperature, complexes obtained were filtered, washed thoroughly with ethanol, DMF and petroleum ether to remove unreacted ligand and metal salt. Finally all complexes dried under vacuum at room temperature (yield: $65-70 \%$ ).

Synthesis of $\mathrm{WO}_{2}(\mathrm{VI})$ complex

Sodium tungstate dihydrate $(1.2 \mathrm{~g}, 0.00363 \mathrm{~mol})$ and ammonium thiocyanate $(2.9 \mathrm{~g} .0 .038 \mathrm{~mol})$ were dissolved in water $(30 \mathrm{~mL})$ at room temperature and $7.5 \mathrm{~mL}$ of $11 \mathrm{M} \mathrm{HCl}$ was added to it. The resulting yellow solution was cooled in an ice bath and to this a hot DMF solution $(10 \mathrm{~mL})$ of ligand $(0.00363 \mathrm{~mol})$ was added with continuous stirring. The precipitate so formed was filtered under suction, washed 3-4 times with water containing few drops of $\mathrm{HCl}$ and dried in vacuo.

\section{Physical measurements}

Elemental analysis carbon, hydrogen and nitrogen were obtained using Carlo Erba 1108 analyser in microanalytical laboratory, SAIF, CDRI, Lucknow. IR spectra were recorded on a Perkin-Elmer 597 spectrophotometer using KBr pellets at SAIF Punjab University, Chandigarh. ${ }^{1} \mathrm{H}-\mathrm{NMR}$ spectrum of ligand was obtained using a Bruker Auance-II 400 NMR spectrophotometer in DMSO solvent at SAIF Punjab University, Chandigarh. The reflectance spectra of the complexes were recorded on Varian SE UV-NIR spectrophotometer at SAIF, IIT, Chennai using $\mathrm{MgO}$ as reference. Magnetic susceptibility was measured at room temperature by Gouy's method using $\mathrm{Hg}\left[\mathrm{Co}(\mathrm{NCS})_{4}\right]$ as a calibrant and the diamagnetic corrections were made using Pascal's constants. The solid state electrical conductivity of compounds was measured by Zentech Electrometer in their compressed pellet form over 313-403 K temperature range. Thermogravimetric analysis of the complexes was carried out on Perkin Elmere TG-2 thermobalance in ambient air with a heating rate of $10{ }^{\circ} \mathrm{C} / \mathrm{min}$. Metal contents of the complexes were analysed gravimetrically after decomposing the complexes with a mixture of $\mathrm{HClO}_{4}$, $\mathrm{H}_{2} \mathrm{SO}_{4}$ and $\mathrm{HNO}_{3}$ and then igniting to metal oxide. The XRD measurement of the complexes was recorded on a Bruker AXS, D8-ADVANCE (Gmbh, Karlsryhe, Germany) equipped with $\theta / \theta$ gonimeter and a Lynv Eye detector. Qualitative and quantities analysis of products and reactant were measured on GC (Shimandzu 14B Gas chromatography equipped with SE-30 column and FID detector.

\section{Oxidation of styrene}

The oxidation of styrene was tested with VO(IV) and Mn(III) complexes as representative cases. The catalytic reactions were carried out in $250 \mathrm{~mL}$ reaction flask fitted with water condenser and a similar procedure was used in both the reactions. In a typical experiment, styrene $(1.04 \mathrm{~g}$, $10 \mathrm{mmol})$ and aqueous $30 \% \mathrm{H}_{2} \mathrm{O}_{2}(2.27 \mathrm{~g}, 20 \mathrm{mmol})$ were mixed in $10 \mathrm{~mL}$ of $\mathrm{MeCN}$ and the reaction mixture was heated with continuous stirring $8 \mathrm{~h}$ in an oil bath at $80{ }^{\circ} \mathrm{C}$. An appropriate amount of catalyst $(0.020 \mathrm{~g})$ was added to the reaction mixture and reaction was considered to begin. The reaction was monitored at various time periods and checked by the gas chromatography. The effect of catalyst concentration with styrene was also studied to obtained suitable reaction conditions for oxidation of styrene.

\section{RESULTS AND DISCUSSION}

The reaction of 5-chloro-2-hydroxyacetophenone and 2-hydroxy-5-methyl-3-nitro acetophenone with carbohydrazide in hot DMF-ethanol yields the Schiff base $\left(\mathrm{H}_{2} \mathrm{~L}\right)$. The reaction of $\mathrm{H}_{2} \mathrm{~L}$ in DMF and appropriate metal salts in ethanol gives the complexes. The analytical data of the 
ligand and its complexes are given in Table 1. All the complexes are coloured solids, nonhygroscopic, air stable and insoluble in water and common organic solvents but sparingly soluble in DMSO. The elemental analysis shows 1:1 metal to ligand stoichiometry for all the complexes.

\section{IR spectra}

The IR spectra of the complexes are compared with those of the free ligand in order to determine the coordination sites that may be involved in chelation. The FT-IR spectrum of the free ligand shows characteristic band at $2998 \mathrm{~cm}^{-1}$, assignable to $v(\mathrm{OH})$ intramolecular hydrogen bonding between phenolic hydrogen and azomethine nitrogen atoms, which disappears in the spectra of metal complexes, indicating deprotonation of the $\mathrm{OH}$ group upon binding with metal ions. This is further supporting by shifting of the $v(\mathrm{CO})$ (phenolic) band at $1263 \mathrm{~cm}^{-1}$, to a higher frequency in complexes, suggesting the coordination of ligand through phenolic oxygen via deprotonation $[12,13]$. The band at $1654 \mathrm{~cm}^{-1}$ (azomethine $\mathrm{C}=\mathrm{N}$ ) shifted position on complexation [14-16]. The $v(\mathrm{~N}-\mathrm{H})$ and $v(\mathrm{C}=\mathrm{O})$ bands of the ligand at 3288 and $1717 \mathrm{~cm}^{-1}$ do not change their position after complexation, indicating that ligand exist in keto form in free state as well as in all the complexes [17]. The coordination of the acetate group is confirmed due to the difference between the two bands $\left(\Delta v>181 \mathrm{~cm}^{-1}\right)$ in $\mathrm{Mn}$ (III) complex, appeared at 1621 and $1440 \mathrm{~cm}^{-1}$ which are assignable to $v_{\text {sym }}(\mathrm{OCO})$ and $v_{\text {sym }}(\mathrm{OCO})$ mode [18, 19]. A broad and strong band centred in the region 3300-3500 $\mathrm{cm}^{-1}$ and another sharp shoulder in the region $1650-1500 \mathrm{~cm}^{-1}$ may be assigned to $v(\mathrm{OH})$ and $v(\mathrm{HOH})$ vibrations of water molecules, respectively [20]. The additional strong and sharp band at $870-818 \mathrm{~cm}^{-1}$ arising due to $\mathrm{OH}$ rocking vibrations in the spectra of complexes further confirms the presence of coordinated water molecules [20]. The coordination of water in $\mathrm{VO}(\mathrm{IV}), \mathrm{Cr}(\mathrm{III}), \mathrm{Fe}(\mathrm{III})$ and $\mathrm{Zr}(\mathrm{IV})$ complexes is indicated by the appearance of bands at 3429-3357, 1656-1581, 878-840 and 781-765 $\mathrm{cm}^{-1}$ assignable to $\gamma(\mathrm{O}-\mathrm{H}), \delta(\mathrm{O}-\mathrm{H}), \rho_{\mathrm{r}}\left(\mathrm{H}_{2} \mathrm{O}\right)$ and $\rho_{\mathrm{w}}\left(\mathrm{H}_{2} \mathrm{O}\right)$ mode, respectively [20]. The spectra of $\mathrm{VO}(\mathrm{IV})$ and $\mathrm{Zr}(\mathrm{IV})$ complexes show new bands at around 973 and 1129 $\mathrm{cm}^{-1}$, respectively, due to $v(\mathrm{~V}=\mathrm{O})$ and $v(\mathrm{ZrOH})$ vibration. Also, the absence of a new band at $850-950 \mathrm{~cm}^{-1}$ in $\mathrm{Zr}(\mathrm{IV})$ complex due to $\mathrm{v}(\mathrm{Zr}=\mathrm{O})$ stretch. The $\mathrm{MoO}_{2}(\mathrm{VI}), \mathrm{UO}_{2}(\mathrm{VI}), \mathrm{WO}_{2}(\mathrm{VI})$ complexes show new bands around $956,960,943 \mathrm{~cm}^{-1}$ due to $v_{\text {asym }}(\mathrm{O}=\mathrm{Mo}=\mathrm{O}), \mathrm{v}_{\text {asym }}(\mathrm{O}=\mathrm{U}=\mathrm{O})$ and $v_{\text {asym }}(\mathrm{O}=\mathrm{W}=\mathrm{O})$ vibrations [21]. The $\mathrm{WO}_{2}(\mathrm{VI})$ complex shows bands around $2063(\mathrm{CN}), 776$ (CS) and $468 \mathrm{~cm}^{-1}$ (NCS) suggesting that the thiocyanate group act as ligand in which bonding through nitrogen takes place [22]. The IR spectra of complexes show new bands in the region 584-558 and 487-451 $\mathrm{cm}^{-1}$ due to $v(\mathrm{M}-\mathrm{O})$ and $v(\mathrm{M}-\mathrm{N})$ vibrations respectively indicating the coordination of ligand through phenolic oxygen and azomethine nitrogen atoms.

\section{Electronic spectra}

The electronic spectrum of VO(IV) complex shows three bands at 10965, 18904 and $25974 \mathrm{~cm}^{-1}$ due to $d_{x y}\left(b_{2}\right) \rightarrow d_{x y} d_{y z}\left(e^{*}\right), d_{x y}\left(b_{2}\right) \rightarrow d_{x 2-y 2}\left(b_{1}{ }^{*}\right)$ and $d_{x y}\left(b_{2}\right) \rightarrow d_{z 2}\left(a_{1}{ }^{*}\right)$, transitions, respectively, towards square pyramidal geometry of complex. The $\mathrm{Cr}$ (III) complex shows absorption bands at 16366, 21367 and $36496 \mathrm{~cm}^{-1}$ due to ${ }^{4} \mathrm{~A}_{2 \mathrm{~g}}(\mathrm{~F}) \rightarrow{ }^{4} \mathrm{~T}_{2 \mathrm{~g}}(\mathrm{~F}),{ }^{4} \mathrm{~A}_{2 \mathrm{~g}}(\mathrm{~F}) \rightarrow{ }^{4} \mathrm{~T}_{1 \mathrm{~g}}(\mathrm{~F})$ and ${ }^{4} \mathrm{~A}_{2 \mathrm{~g}}(\mathrm{~F})$ $\rightarrow{ }^{4} \mathrm{~T}_{1 \mathrm{~g}}(\mathrm{P})$, transitions, respectively, indicating an octahedral geometry around the $\mathrm{Cr}(\mathrm{III})$ ion $[23,24]$. The ligand field parameters, Dq, Racahinter electronic repulsion parameter (B'), nephelauxetic ratio $(\beta)$ and \% covalency of metal-ligand bond have been calculated for $\mathrm{Cr}(\mathrm{III})$ complex and the values of Dq, B', $\beta, v_{2} / v_{1}$ and \% covalency are found to be $1636.6 \mathrm{~cm}^{-1}, 584$ $\mathrm{cm}^{-1}, 0.636,1.30$ and 36.4. The Racahinter electronic repulsion parameter (B') for complex is found to be lower than the free ion values $\left(918 \mathrm{~cm}^{-1}\right)$ suggesting delocalization of electron on metal into molecular orbital covering both the metal and the ligand, i.e. the appreciable covalent 
character in the metal-ligand bond. The $v_{2} / v_{1}$ is found to be 1.30 which is very close to the value (1.42) reported for octahedral $\mathrm{Cr}$ (III) complex. The $\mathrm{Mn}$ (III) complex shows absorption bands at 13605, 17212, 19646 and $28902 \mathrm{~cm}^{-1}$, corresponds to ${ }^{5} \mathrm{~B}_{1} \rightarrow{ }^{5} \mathrm{~B}_{2},{ }^{5} \mathrm{~B}_{1} \rightarrow{ }^{5} \mathrm{~A}_{1}$ and ${ }^{5} \mathrm{~B}_{1} \rightarrow{ }^{5} \mathrm{E}$ and LMCT transitions respectively towards square pyramidal geometry around metal ion [25]. The Fe(III) complex shows absorption bands at 13369,16000 and $22883 \mathrm{~cm}^{-1}$ corresponding to ${ }^{6} \mathrm{~A}_{1 \mathrm{~g}} \rightarrow{ }^{4} \mathrm{~T}_{1 \mathrm{~g}},{ }^{6} \mathrm{~A}_{1 \mathrm{~g}} \rightarrow{ }^{4} \mathrm{~T}_{2 \mathrm{~g}}$ and ${ }^{6} \mathrm{~A}_{1 \mathrm{~g}} \rightarrow{ }^{4} \mathrm{E}_{\mathrm{g}}$, transitions, respectively, towards an octahedral geometry.

\section{Magnetic properties}

The magnetic susceptibility of the VO(IV), $\mathrm{Cr}(\mathrm{III}), \mathrm{Mn}(\mathrm{III})$ and $\mathrm{Fe}(\mathrm{III})$ complexes was measured at room temperature. The observed magnetic moment for $\mathrm{VO}(\mathrm{IV}), \mathrm{Cr}(\mathrm{III}), \mathrm{Mn}$ (III) and $\mathrm{Fe}(\mathrm{III})$ complexes at room temperature is $1.63,3.88,4.69$ and 5.88 B.M., respectively. A magnetic moment value of complexes which is close to the spin only values suggests their high spin nature. These value supports to the literature value of these complexes. The $\mathrm{MoO}_{2}(\mathrm{VI}), \mathrm{WO}_{2}(\mathrm{VI}), \mathrm{Zr}(\mathrm{IV})$ and $\mathrm{UO}_{2}(\mathrm{VI})$ complexes are found to be diamagnetic as expected from their electronic configurations.

Table 1. Analytical and electrical conductivity data of $\mathrm{H}_{2} \mathrm{~L}$ complex.

\begin{tabular}{|c|l|l|c|c|c|c|c|c|}
\hline $\begin{array}{c}\mathrm{S} . \\
\text { No. }\end{array}$ & $\begin{array}{l}\text { Proposed composition } \\
\text { of the complexes }\end{array}$ & $\sigma\left(\Omega^{-1} \mathrm{~cm}^{-1}\right.$ & \multirow{2}{*}{$\begin{array}{c}\mathrm{E}_{\mathrm{a}} \\
(\mathrm{eV})\end{array}$} & & \multicolumn{3}{c|}{ Colour } & \multicolumn{3}{|c|}{$\begin{array}{c}\text { Elemental analysis \% found } \\
\text { (calculated }\end{array}$} \\
\cline { 6 - 9 } & & & & & $\mathrm{M}$ & $\mathrm{C}$ & $\mathrm{H}$ & $\mathrm{N}$ \\
\hline 1 & $\mathrm{H}_{2} \mathrm{~L}$ & $3.31 \times 10^{-12}$ & 0.160 & $\begin{array}{c}\text { Lemmon } \\
\text { lime }\end{array}$ & -- & $\begin{array}{c}50.23 \\
(51.50)\end{array}$ & $\begin{array}{c}4.04 \\
(4.32)\end{array}$ & $\begin{array}{c}15.70 \\
(16.68)\end{array}$ \\
\hline 2 & $\left\{[\mathrm{VOL}] \mathrm{H}_{2} \mathrm{O}\right\}$ & $6.98 \times 10^{-12}$ & 0.089 & $\begin{array}{c}\text { Dark } \\
\text { evergreen }\end{array}$ & $\begin{array}{c}9.71 \\
(10.13)\end{array}$ & $\begin{array}{c}42.12 \\
(43.00)\end{array}$ & $\begin{array}{c}3.20 \\
(3.61)\end{array}$ & $\begin{array}{c}12.27 \\
(13.93)\end{array}$ \\
\hline 3 & $\left\{\left[\mathrm{CrL} \cdot \mathrm{H}_{2} \mathrm{O} \cdot \mathrm{Cl}\right] \cdot \mathrm{H}_{2} \mathrm{O}\right\}$ & $9.77 \times 10^{-10}$ & 0.214 & Umber & $\begin{array}{c}8.87 \\
(9.61)\end{array}$ & $\begin{array}{c}38.67 \\
(39.94)\end{array}$ & $\begin{array}{c}3.19 \\
(3.72)\end{array}$ & $\begin{array}{c}11.82 \\
(12.94)\end{array}$ \\
\hline 4 & {$[\mathrm{MnL} \cdot \mathrm{OAc}]$} & $1.58 \times 10^{-09}$ & 0.249 & Dark orange & $\begin{array}{c}9.64 \\
(10.33)\end{array}$ & $\begin{array}{c}44.33 \\
(45.17)\end{array}$ & $\begin{array}{c}2.92 \\
(3.60)\end{array}$ & $\begin{array}{c}12.22 \\
(13.17)\end{array}$ \\
\hline 5 & $\left\{\left[\mathrm{FeL} \cdot \mathrm{H}_{2} \mathrm{O} \cdot \mathrm{Cl}\right] \cdot \mathrm{H}_{2} \mathrm{O}\right\}$ & $8.13 \times 10^{-12}$ & 0.162 & Maroon & $\begin{array}{c}9.37 \\
(10.24)\end{array}$ & $\begin{array}{c}38.42 \\
(39.66)\end{array}$ & $\begin{array}{c}2.81 \\
(3.70)\end{array}$ & $\begin{array}{c}11.09 \\
(12.85)\end{array}$ \\
\hline 6 & $\left\{\left[\mathrm{ZrL}(\mathrm{OH})_{2} \mathrm{H}_{2} \mathrm{O}\right] \mathrm{H}_{2} \mathrm{O}\right\}$ & $3.02 \times 10^{-10}$ & 0.222 & Safari & $\begin{array}{c}14.94 \\
(15.75)\end{array}$ & $\begin{array}{c}35.97 \\
(37.33)\end{array}$ & $\begin{array}{c}3.09 \\
(3.83)\end{array}$ & $\begin{array}{c}11.48 \\
(12.09)\end{array}$ \\
\hline 7 & {$\left[\mathrm{MoO}_{2} \mathrm{~L}\right]$} & $2.34 \times 10^{-09}$ & 0.270 & Orange & $\begin{array}{c}16.88 \\
(17.58)\end{array}$ & $\begin{array}{c}38.41 \\
(39.61)\end{array}$ & $\begin{array}{c}2.38 \\
(2.96)\end{array}$ & $\begin{array}{c}11.68 \\
(12.83)\end{array}$ \\
\hline 8 & {$\left[\mathrm{WO}_{2} \mathrm{~L} \cdot \mathrm{NCS}\right]$} & $1.26 \times 10^{-07}$ & 0.226 & Light yellow & $\begin{array}{c}25.49 \\
(26.58)\end{array}$ & $\begin{array}{c}31.79 \\
(32.99)\end{array}$ & $\begin{array}{c}1.95 \\
(2.33)\end{array}$ & $\begin{array}{c}11.54 \\
(12.15)\end{array}$ \\
\hline 9 & {$\left[\mathrm{UO}_{2} \mathrm{~L}\right]$} & $1.26 \times 10^{-09}$ & 0.260 & $\begin{array}{c}\text { Dark red } \\
\text { gray }\end{array}$ & $\begin{array}{c}33.77 \\
(34.61)\end{array}$ & $\begin{array}{c}30.90 \\
(31.43)\end{array}$ & $\begin{array}{c}1.98 \\
(2.34)\end{array}$ & $\begin{array}{c}9.81 \\
(10.18)\end{array}$ \\
\hline
\end{tabular}

\section{Electrical conductivity measurements}

The solid state d.c. electrical conductivity was measured in a compressed pellet form over a temperature range $313-413 \mathrm{~K}$ and values reported in Table 1 . The electrical conductivity $(\sigma)$ varies experimentally with the absolute temperature according to the relation $\sigma=\sigma^{0} \exp \left(\mathrm{E}_{\mathrm{a}} / \mathrm{KT}\right)$ where $\sigma^{0}$ is constant, $E_{a}$ is the activation energy of electrical conduction, $T$ is the absolute temperature and $\mathrm{K}$ is Boltzman constant. The plots of $\log \sigma$ vs. 1/T are found to be linear over studied temperature range and conductivity increases with increasing temperature. This suggests that the compounds behave as a semiconducting material $[26,27]$. The solid state d.c. electrical conductivity lies in the ranges $3.31 \times 10^{-12}$ to $1.26 \times 10^{-7} \Omega^{-1} \mathrm{~cm}^{-1}$ and the decreasing in the order $\mathrm{WO}_{2}>\mathrm{MoO}_{2}>\mathrm{Mn}>\mathrm{UO}_{2}>\mathrm{Cr}>\mathrm{Zr}>\mathrm{Fe}>\mathrm{VO}>\mathrm{H}_{2} \mathrm{~L}$. 


\section{Oxidation of styrene}

The catalytic oxidation of styrene gives the products styrene oxide, benzaldehyde, benzoic acid, phenyl acetic acid and 1-phenyl etheane-1,2-diol and other side products [28]. In the present study oxidation of styrene catalysed by the VO(IV) and Mn(III) complexes was carried out. The catalytic activity of these complexes was checked as a function of the amount of catalyst and $\mathrm{H}_{2} \mathrm{O}_{2}$ used as oxidant. The amount of catalyst is used like $0.020,0.030$ and $0.040 \mathrm{~g}$, respectively, amount of styrene and $\mathrm{H}_{2} \mathrm{O}_{2}(1: 2)$ was fixed in presence of acetonitrile at $80{ }^{\circ} \mathrm{C}$. The conversion of styrene in $\mathrm{VO}(\mathrm{IV})$ and $\mathrm{Mn}(\mathrm{III})$ complexes was $11.14-24.35 \%$ and $9.64-23.42 \%$, respectively (Table 2, Figures 2 and 3), which show extremely low product selectivity of styrene oxide $(>3 \%)$ in optimized condition within $8 \mathrm{~h}$. But the product selectivity of benzaldehyde is greater $(<65 \%)$ this may due to the strong oxidizing nature of $\mathrm{H}_{2} \mathrm{O}_{2}$, the styrene oxide formed in the first step by epoxidation is mainly converted into benzaldehyde via hydroperoxistyrene as an intermediate. Further this may be by direct oxidative cleavage of the styrene side chain double bond via a radical mechanism. The conversion of styrene increases with increase in amount of catalyst in presence of fixed amount of $\mathrm{H}_{2} \mathrm{O}_{2}$ and styrene in case of $\mathrm{VO}(\mathrm{IV})$ complex catalyst while in $\mathrm{Mn}(\mathrm{III})$ complex with increase in catalyst decrease in conversion of styrene. This may be due to the electron rich metal centre of complex and it may have access and hence the formation of metal oxo species is easy than electron deficient metal centre complex and hence

Table 2. Catalytic activity of $\mathrm{H}_{2} \mathrm{~L}$ complexes.

\begin{tabular}{|c|c|c|c|}
\hline S. No. & Complexes & Amount of catalyst $(\mathrm{g})$ & \% Conversion \\
\hline \multirow{3}{*}{1} & \multirow{3}{*}{$[\mathrm{VOL}] \mathrm{H}_{2} \mathrm{O}$} & 0.020 & 11.14 \\
\cline { 3 - 4 } & & 0.030 & 19.60 \\
\cline { 3 - 4 } & & 0.040 & 24.35 \\
\hline \multirow{3}{*}{2} & \multirow{3}{*}[\mathrm{MnL}\cdot\mathrm{OAc}]{} & 0.020 & 9.64 \\
\cline { 3 - 4 } & & 0.030 & 16.8 \\
\cline { 3 - 4 } & & 0.040 & 23.42 \\
\hline
\end{tabular}

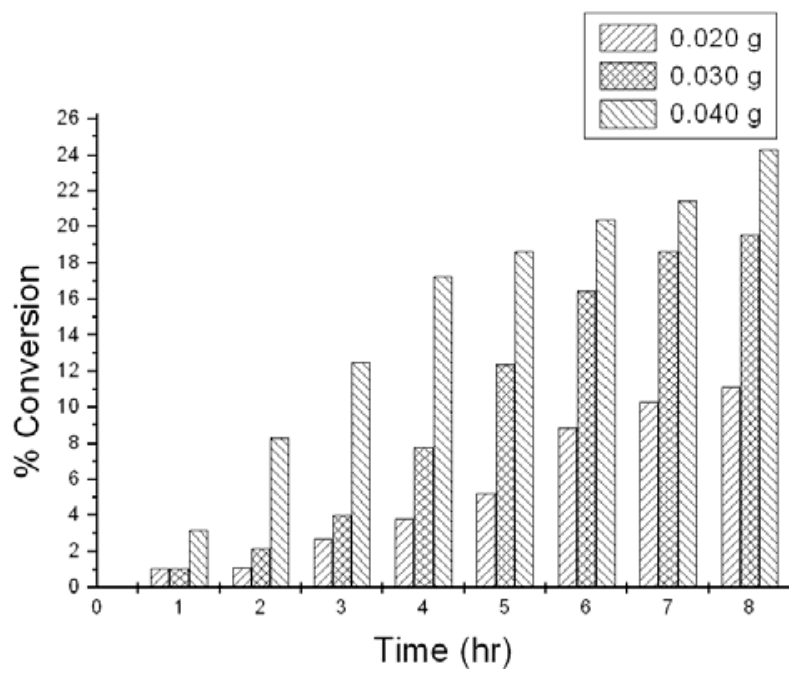

Figure 2. Effect of $\left\{[\mathrm{VOL}] \mathrm{H}_{2} \mathrm{O}\right\}$ complex catalyst on \% styrene conversion.

Bull. Chem. Soc. Ethiop. 2015, 29(3) 


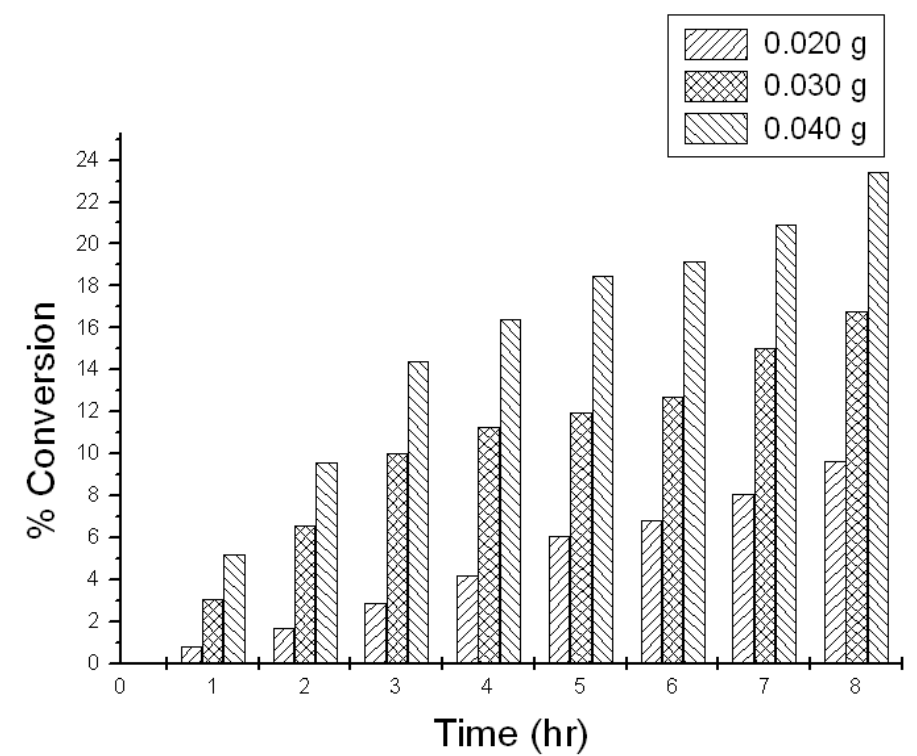

Figure 3. Effect of [MnL·OAc] complex catalyst on \% styrene conversion.

conversion is vary in VO(IV) and Mn(III) complexes [29]. The percentage conversion of styrene was decreases significantly this may be due degradation of the catalyst. The proposed mechanism for oxidation of styrene by $\mathrm{H}_{2} \mathrm{O}_{2}$ with $\mathrm{VO}(\mathrm{IV})$ complex is shown in Figure 4. A blank experiment was performed in each case, where in the absence of catalyst no epoxide was formed under the same reaction condition.

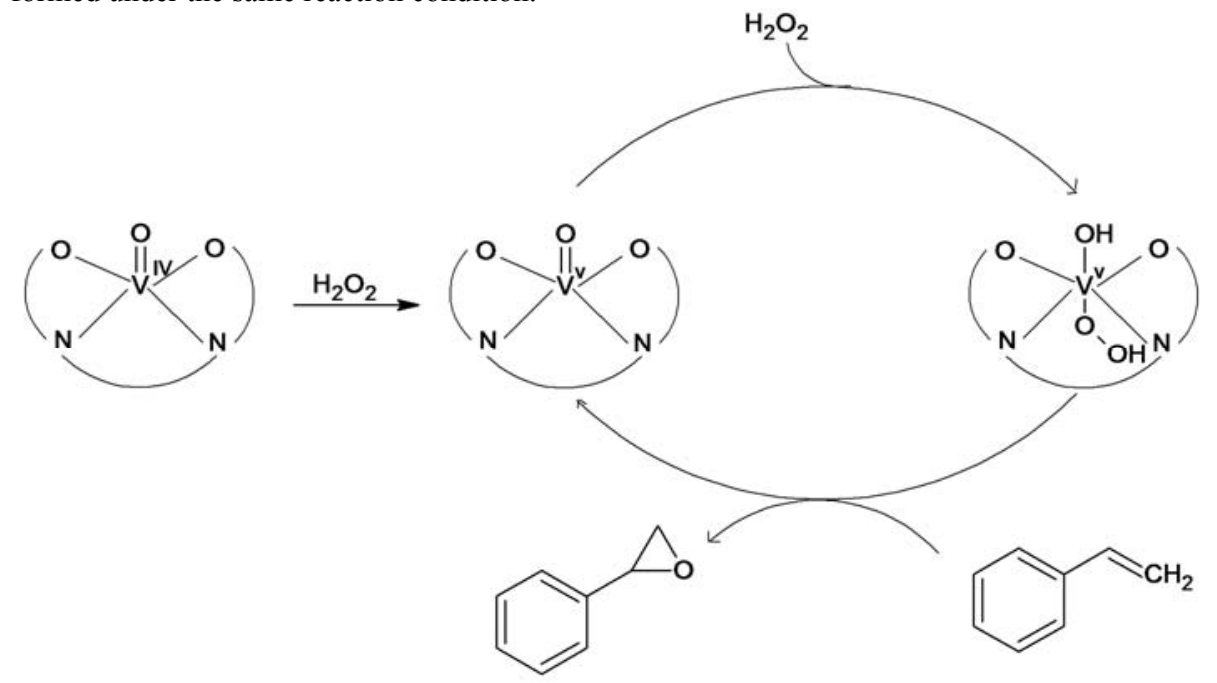

Figure 4. The proposed mechanism of the epoxidation of styrene by $\mathrm{VO}(\mathrm{IV})$ complex in the presence of $\mathrm{H}_{2} \mathrm{O}_{2}$.

Bull. Chem. Soc. Ethiop. 2015, 29(3) 


\section{Thermogravimetric study}

Thermal studies of ligand and its complexes were carried out at a heating rate of $10{ }^{\circ} \mathrm{C} / \mathrm{min}$ to observe their thermal behaviour and thermograms indicate the presence of lattice/coordinated water in complexes. The thermograms of $\mathrm{Cr}(\mathrm{III}), \mathrm{Fe}(\mathrm{III})$ and $\mathrm{Zr}(\mathrm{IV})$ complexes indicate three stage decomposition pattern, whereas $\mathrm{VO}(\mathrm{IV}), \mathrm{Mn}(\mathrm{III}), \mathrm{MoO}_{2}(\mathrm{VI}), \mathrm{WO}_{2}(\mathrm{VI})$ and $\mathrm{UO}_{2}(\mathrm{VI})$ complexes show two stage decomposition. The TG analysis of $\mathrm{VO}(\mathrm{IV}), \mathrm{Cr}(\mathrm{III}), \mathrm{Fe}(\mathrm{III})$ and $\mathrm{Zr}(\mathrm{IV})$ complexes shows elimination of a water molecule takes place at $70-110{ }^{\circ} \mathrm{C}$ indicating the presence of lattice water molecule whereas $\mathrm{Cr}$ (III), $\mathrm{Fe}$ (III) and $\mathrm{Zr}(\mathrm{IV})$ complexes shows water elimination at $130-225{ }^{\circ} \mathrm{C}$ indicating the presence of an coordinated water molecule in the complexes [\% wt. loss, obs./calcd. VO(IV): 3.92/3.58; Cr(III): 3.76/3.32; Fe(III): 3.72/3.30 and $\mathrm{Zr}(\mathrm{IV}): 3.53 / 3.10$ for lattice water and $\mathrm{Cr}(\mathrm{III})$ : 3.66/3.32; $\mathrm{Fe}(\mathrm{III}): 3.68 / 3.30$ and $\mathrm{Zr}(\mathrm{IV})$ : $3.57 / 3.10$ for coordinated water]. The thermogram of Mn(III) complexes is almost stable up to $245{ }^{\circ} \mathrm{C}$ and thereafter it shows gradual loss upto $\sim 310{ }^{\circ} \mathrm{C}$ corresponding to one mole of acetate group. $\mathrm{MoO}_{2}(\mathrm{VI}), \mathrm{WO}_{2}(\mathrm{VI})$ and $\mathrm{UO}_{2}(\mathrm{VI})$ complexes are almost stable up to $190{ }^{\circ} \mathrm{C}$ indicating that absence of any lattice or coordinated water molecule in their complexes. The $\mathrm{WO}_{2}(\mathrm{VI})$ complex shows loss in range the $185-234{ }^{\circ} \mathrm{C}$ which corresponds to loss of one thiocyanato group. In all complexes, a rapid weight-loss between $275-420{ }^{\circ} \mathrm{C}$ due to quantitative elimination of ligand followed by a gradual weight loss up to $690{ }^{\circ} \mathrm{C}$ due to complete decomposition of coordinated ligand. The thermal degradation of the ligand molecule is observed in complexes by gradual weight-loss in the range $310-690{ }^{\circ} \mathrm{C}$. Above $690{ }^{\circ} \mathrm{C}$, nature of the curve is almost horizontal indicating the formation of corresponding metallic oxides. The half decomposition temperature and the kinetic parameters calculated for the compounds are given in Table 3 . The relative thermal stability on the basis of half composition temperature is found to be: $\mathrm{VO}(\mathrm{IV})>$ $\mathrm{Fe}(\mathrm{III})>\mathrm{Cr}(\mathrm{III})>\mathrm{Mn}(\mathrm{III})>\mathrm{Zr}(\mathrm{IV})>\mathrm{UO}_{2}(\mathrm{VI})>\mathrm{WO}_{2}(\mathrm{VI})>\mathrm{MoO}_{2}(\mathrm{VI})>\mathrm{H}_{2} \mathrm{~L}$. From the thermal decomposition data various kinetic and thermodynamic parameters such as energy of activation $\left(E_{a}\right)$, frequency factor $(Z)$ and entropy change $(-\Delta S)$ have been evaluated by employing Horowitz-Metzger method and values are summarized in Table 3. The activation energies of decomposition are found in the range 34.91-74.55 $\mathrm{KJmol}^{-1}$. The obtained high values of the activation energy of complexes may be due to the stability of chelation due to their coordinated bond and it suggested predicting the bond strength of ligand towards the metal ions and also revealed that the decrease in their atomic radii [30]. The positive sign of $\Delta G$ for the complexes reveals that the free energy of the final products is higher than that of the initial compound, and all the decomposition steps are non-spontaneous process. Also the values of $\Delta \mathrm{G}$ increase significantly for subsequent decomposition steps of the complexes. This is due to the increasing the values of $\Delta \mathrm{S}$ significantly from one step to another in the complexes. The negative values of $\Delta \mathrm{S}$ indicate a more ordered activated state that may be possible through the chemisorptions of oxygen and other decomposition products. The more ordered nature may be due to the polarization of bonds in activated state which might happen through charge transfer of electronic transitions.

\section{Powder XRD study}

The $\left\{[\mathrm{VOL}] \mathrm{H}_{2} \mathrm{O}\right\}$ complex was subjected to powder X-ray diffraction analysis (Figure 5). The presence of sharp reflections in XRD pattern of $\left\{[\mathrm{VOL}] \mathrm{H}_{2} \mathrm{O}\right\}$ indicates the crystalline nature of compound. The XRD spectrum has been recorded with $\mathrm{Cu} \mathrm{K} \alpha \mathrm{X}$ ray tube in the range $2 \theta=4$ $35^{\circ}$ with $\lambda=1.5406 \AA$. All the main peaks have been indexed by using appropriate methodology and use of computer program (PowdMult, Version 2.3). The indexing is confirmed on the basis of correction obtained between observed and calculated values. The $2 \theta$ values and relative intensities corresponding to the prominent peaks have been listed in Table 4 . The $2 \theta$ values and relative intensities corresponding to the prominent peaks have been listed in Table 4 . The unit 
cell lattice parameter of $\left\{[\right.$ VOL $\left.] \mathrm{H}_{2} \mathrm{O}\right\}$ complex are $\mathrm{a}=16.2604 \AA, \mathrm{b}=10.0403 \AA, \mathrm{c}=6.7669 \AA$, $\alpha=98.342^{\circ}, \beta=108.203^{\circ}, \gamma=91.858^{\circ}$, volume $(V)=1034.80 \AA^{3}$ belongs to triclinic system.

Table 3. Thermal decomposition data of $\mathrm{H}_{2} \mathrm{~L}$ and its complexes.

\begin{tabular}{|c|c|c|c|c|c|c|}
\hline $\begin{array}{l}\text { S. } \\
\text { No. }\end{array}$ & Compound & $\begin{array}{c}\mathrm{MP}^{*} / \text { half } \\
\text { decomp. temp. } \\
\left({ }^{\circ} \mathrm{C}\right)\end{array}$ & 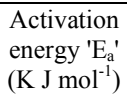 & $\begin{array}{c}\text { Frequency } \\
\text { factor ' } \mathrm{Z} \text { ' } \\
\left(\mathrm{s}^{-1}\right)\end{array}$ & $\begin{array}{c}\text { Entropy } \\
\text { change ' } \Delta \mathrm{S}^{\prime} \\
\left(\mathrm{J} \mathrm{mol}^{-1} \mathrm{~K}^{-1}\right)\end{array}$ & $\begin{array}{c}\text { Free Energy } \\
\text { Change ' } \Delta \mathrm{G}^{\prime} \\
\left(\mathrm{K} \mathrm{J} \mathrm{mol} \mathrm{mol}^{-1}\right)\end{array}$ \\
\hline 1. & $\mathrm{H}_{2} \mathrm{~L}$ & 313 & 34.91 & 37.14 & -26.52 & 50.45 \\
\hline 2. & $\left\{[\mathrm{VOL}] \mathrm{H}_{2} \mathrm{O}\right\}$ & 412 & 46.01 & 31.67 & -26.83 & 64.39 \\
\hline 3. & $\left\{\left[\mathrm{Cr} \mathrm{L} \cdot \mathrm{H}_{2} \mathrm{O} \cdot \mathrm{Cl}\right] \cdot \mathrm{H}_{2} \mathrm{O}\right\}$ & 394 & 56.21 & 44.42 & -26.47 & 73.87 \\
\hline 4. & {$[\mathrm{MnL} \cdot \mathrm{OAc}]$} & 365 & 23.70 & 11.97 & -27.74 & 41.39 \\
\hline 5. & $\left\{\left[\mathrm{FeL} \cdot \mathrm{H}_{2} \mathrm{O} \cdot \mathrm{Cl}\right] \cdot \mathrm{H}_{2} \mathrm{O}\right\}$ & 411 & 41.17 & 43.88 & -26.51 & 59.30 \\
\hline 6. & $\left\{\left[\mathrm{ZrL}(\mathrm{OH})_{2} \mathrm{H}_{2} \mathrm{O}\right] \mathrm{H}_{2} \mathrm{O}\right\}$ & 356 & 74.55 & 123.52 & -25.39 & 90.52 \\
\hline 7. & {$\left[\mathrm{MoO}_{2} \mathrm{~L}\right]$} & 329 & 39.37 & 55.46 & -26.14 & 55.11 \\
\hline 8. & {$\left[\mathrm{WO}_{2} \mathrm{~L} \cdot \mathrm{NCS}\right]$} & 351 & 21.15 & 14.32 & -27.53 & 38.34 \\
\hline 9. & {$\left[\mathrm{UO}_{2} \mathrm{~L}\right]$} & 355 & 58.06 & 29.91 & -26.80 & 74.89 \\
\hline
\end{tabular}

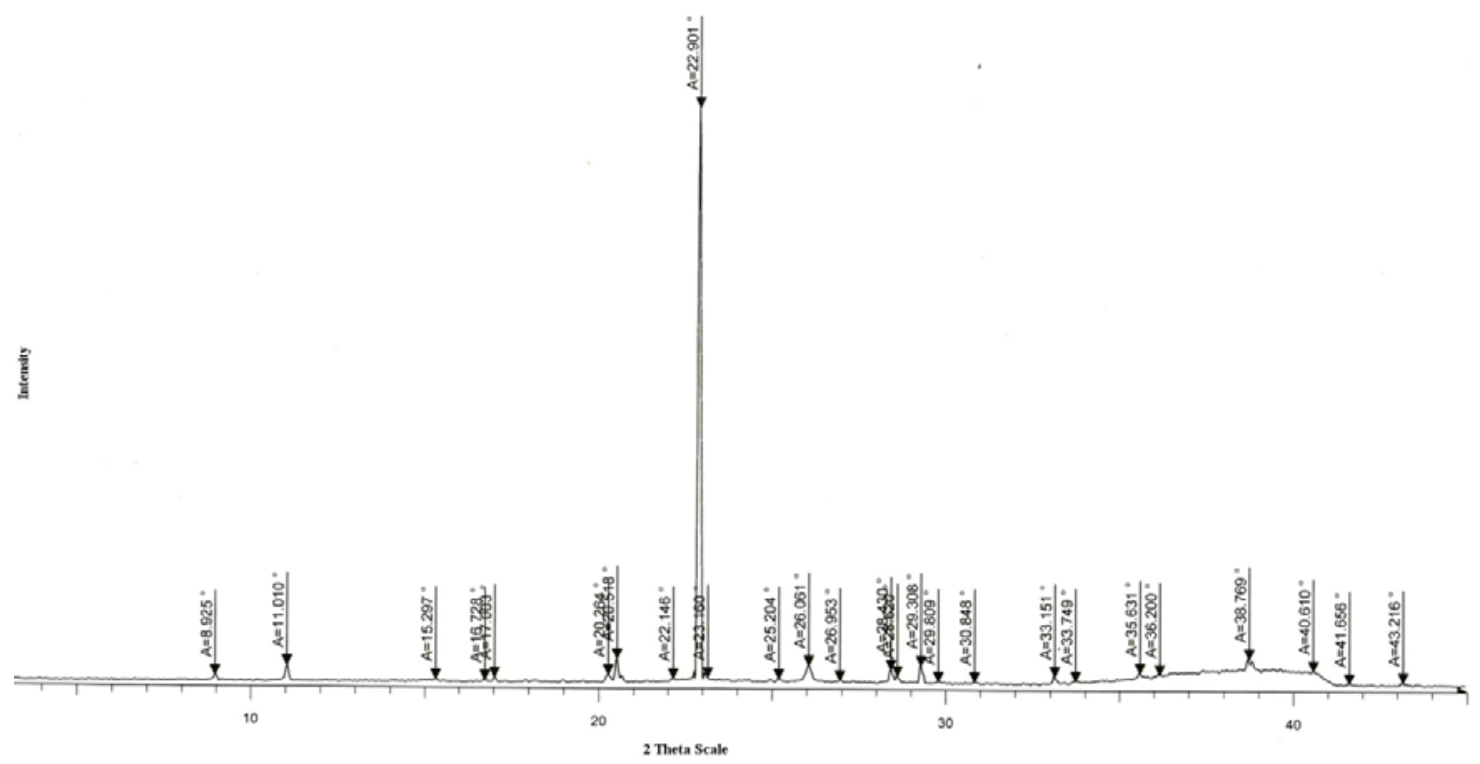

Figure 5. X-ray diffraction spectrum of $\left\{[\mathrm{VOL}] \mathrm{H}_{2} \mathrm{O}\right\}$ complex. 
Table 4. The parameters of unit cell and observed and calculated X-ray diffraction data of $\left\{[\mathrm{VOL}] \mathrm{H}_{2} \mathrm{O}\right\}$ complex.

\begin{tabular}{|c|c|c|c|c|c|c|}
\hline \multicolumn{7}{|c|}{$\begin{array}{l}\text { System: triclinic, } a=16.2604 \AA, b=10.0403 \AA, c=6.7669 \AA, \alpha=98.342^{\circ}, \beta=108.203^{\circ}, \gamma=91.858^{\circ} \\
V=1034.80 \AA^{3}\end{array}$} \\
\hline Peak no. & $\mathrm{d}($ Obs.) & d (Cal.) & $2 \theta$ (Obs.) & $2 \theta$ (Cal.) & $\Delta 2 \theta$ & (h k l) \\
\hline 1 & 9.9000 & 9.9000 & 8.93 & 8.93 & 0.00 & 010 \\
\hline 2 & 8.0300 & 8.0300 & 11.01 & 11.01 & 0.00 & $\begin{array}{lll}1 & 1 & 0\end{array}$ \\
\hline 3 & 5.7870 & 5.7870 & 15.30 & 15.30 & 0.00 & $0-1 \quad 1$ \\
\hline 4 & 5.2960 & 5.2960 & 16.73 & 16.73 & 0.00 & $\begin{array}{lll}1 & 0 & 1\end{array}$ \\
\hline 5 & 5.2100 & 5.2100 & 17.00 & 17.00 & 0.00 & $\begin{array}{lll}-1 & 1 & 1\end{array}$ \\
\hline 6 & 4.3790 & 4.3790 & 20.26 & 20.26 & 0.00 & $\begin{array}{lll}1 & 1 & 1\end{array}$ \\
\hline 7 & 4.3250 & 4.3294 & 20.52 & 20.50 & 0.02 & -220 \\
\hline 8 & 4.0110 & 4.0150 & 22.14 & 22.12 & 0.02 & 220 \\
\hline 9 & 3.8800 & 3.8893 & 22.90 & 22.85 & 0.05 & $\begin{array}{lll}-4 & 0 & 1 \\
\end{array}$ \\
\hline 10 & 3.8370 & 3.8484 & 23.16 & 23.09 & 0.07 & 400 \\
\hline 11 & 3.5310 & 3.5345 & 25.20 & 25.18 & 0.02 & $-3-2 \quad 1$ \\
\hline 12 & 3.4160 & 3.4238 & 26.06 & 26.00 & 0.06 & 320 \\
\hline 13 & 3.3050 & 3.3075 & 26.96 & 26.94 & 0.02 & $-1-12$ \\
\hline 14 & 3.1370 & 3.1315 & 28.43 & 28.48 & -0.05 & $\begin{array}{lll}-1 & -3 & 1 \\
\end{array}$ \\
\hline 15 & 3.1170 & 3.1281 & 28.62 & 28.51 & 0.11 & -230 \\
\hline 16 & 3.0450 & 3.0437 & 29.31 & 29.32 & -0.01 & $5-1 \quad 1$ \\
\hline 17 & 2.9950 & 2.9971 & 29.81 & 29.79 & 0.02 & $\begin{array}{lll}-2 & -3 & 1\end{array}$ \\
\hline 18 & 2.8960 & 2.8950 & 30.85 & 30.86 & -0.01 & $4-1 \quad 1$ \\
\hline 19 & 2.7000 & 2.6981 & 33.15 & 33.18 & -0.03 & $\begin{array}{lll}-6 & 0 & 1\end{array}$ \\
\hline 20 & 2.6540 & 2.6480 & 33.74 & 33.82 & -0.08 & $\begin{array}{lll}2 & 0 & 2 \\
\end{array}$ \\
\hline 21 & 2.5180 & 2.5137 & 35.63 & 35.69 & -0.06 & $2-22$ \\
\hline 22 & 2.4790 & 2.4786 & 36.21 & 36.21 & 0.00 & $\begin{array}{lll}5 & -1 & 1 \\
\end{array}$ \\
\hline 23 & 2.3210 & 2.3208 & 38.77 & 38.77 & 0.00 & $\begin{array}{lll}-7 & 0 & 1 \\
\end{array}$ \\
\hline 24 & 2.2200 & 2.2236 & 40.61 & 40.54 & 0.07 & $\begin{array}{lll}-1 & 4 & 1 \\
\end{array}$ \\
\hline 25 & 2.1660 & 2.1647 & 41.66 & 41.69 & -0.03 & -440 \\
\hline 26 & 2.0920 & 2.0958 & 43.21 & 43.13 & 0.09 & $3-32$ \\
\hline
\end{tabular}

\section{ACKNOWLEDGEMENTS}

The authors wish to thank SAIF Chandigarh and CDRI Lucknow for recording elemental analyses, IR, NMR, electronic spectra and XRD and Dr. R. Prasad, School of Chemical Science, Devi Ahilya University, Indore for gas chromatographic analysis of the compounds.

\section{REFERENCES}

1. Hamurcu, F.; Gunduzalp, A.B.; Cete, S.; Erk, B. Trans. Met. Chem. 2008, 33, 137.

2. Abdallah, S.M.; Zayed, M.A.; Mohamad, G.G. Arab. J. Chem. 2010, 3, 103.

3. Xavier, K.O.; Chako, J.; Yusuff, K.K.M. J. Mol. Catal. A Chem. 2002, 178, 275.

4. Kumar, S.; Dhar, D.N.; Saxena, P.N. J. Sci. Ind. Res. 2009, 68, 181.

5. Cukurovali, A.; Yilmaz, I.; Ozmen. H. Trans. Met. Chem. 2002, 27, 171.

6. Masar, M.S.; Gianneschi, N.C.; Oleveri, C.G.; Stern, C.L.; Nguyen, S.T.; Mirking, C.A. J. Am. Chem. Soc. 2007, 129, 10149.

7. Asadi, M.; Sepehrpour, H.; Mohammadi, K. J. Serb. Chem. Soc. 2011, 76, 63.

8. Yaul, A.R.; Dhande, V.V.; Pethe, G.B.; Aswar, A.S. Bull. Chem. Soc. Ethiop. 2014, 28, 255.

9. Gudasi, K.B.; Patil, S.A.; Bakale, R.P.; Nethaji, M. J. Mol. Struct. 2014, 1065, 179.

10. Christensen, O.T.Z. Anorg. Allg. Chem. 1901, 27, 321. 
11. Pethe, G.B.; Yaul, A.R.; Devhade, J.B.; Aswar, A.S. Der. Pharm. Chem. 2010, 2, 301.

12. Badwaik, V.B.; Aswar, A.S. Russ. J. Inorg. 2009, 54, 1611.

13. Boghaei, D.M.; Sabouncheib, S.J.S.; Rayatib, S. Synth. React. Inorg. Met. Org. Chem. 2000, 30,1535 .

14. Singh, R.V.; Joshi, S.C.; Dwivedi, R. Phos. Sul. Sili. Relat. Elem. 2004, 179, 227.

15. Ray, A.; Pilet, G.; Gomen-Garcia, C.J.; Mitra, S. Polyhedron 2009, 28, 511.

16. Raman, N.; Sakthivel, A.; Raja, J.D.; Rajasekaran, K. Russ. J. Inorg. Chem. 2008, 53, 213.

17. Badwaik, V.B.; Deshmukh, R.D.; Aswar, A.S. Russ. J. Coord. Chem. 2009, 35, 247.

18. Kumar, D.; Syamal, A.; Singh, A.K. Ind. J. Chem. 2003, 42A, 280.

19. Maurya, M.R.; Singh, N. Ind. J. Chem. 2004, 43A, 542.

20. Maurya, M.R.; Singh; D.P.; Varma, S.K. Synth. React. Inorg. Met. Org. Chem. 1989, 19, 923.

21. Nag, J.K.; Pal, S.; Sinha, C. Trans. Met. Chem. 2005, 30, 523.

22. Garg, R.; Fahmim, N.; Singh, R.V. J. Ind. Chem. Soc. 2009, 86, 670.

23. Maldhure, A.K.; Aswar, A.S. J. Ind. Chem. Soc. 2009, 86, 697.

24. Nejo, A.A.; Kolawole, G.A.; Opoku, A.R.; Wolowska, J.; Brien, P.O. Inorg. Chim. Acta 2009, 362, 3993.

25. Grisenti, D.L.; Smith, M.B.; Fang, L.; Bishop, N.; Wagenknecnt, P.S. Inorg. Chim. Acta 2010, 363, 157.

26. Modi, C.K.; Patel, I.A.; Thaker, B.T. J. Coord. Chem. 2008, 61, 3110.

27. Duelund, L.; Hazell, R.; Mckenzie, C.J.; Nielsen, L.P.; Toftlund, H. J. Chem. Soc. Dalton. Trans. 2001, 152.

28. Maurya, M.R.; Chandrakar, A.K.; Chand, S. J. Mol. Cat. A: Chem. 2007, 270, 225.

29. Jacobsen, E.N. Comprehesive Organometallic Chemistry II, Abel, E.W.; Stne, F.G.A.; Wilkinson, G. (Eds.), Pergaon: New York; 1995, p 12.

30. Chaudhary, R.G.; Juneja, H.D.; Gharpure, M.P. J. Therm. Anal. Calorim. 2013, 112, 637. 